\title{
INTRODUCTION
}

Over the past three decades, the number of prisoners has surged in every state in the country (Pew Centre on the States, 2008). This growth resulted, in part, from perceptual changes in how the criminal justice system processed and punished juveniles, women, violent offenders and drug offenders. Prison expansion intensified with 'get tough' legislation that decreased judicial and parole authority using sentencing guidelines, mandatory minimums and three strikes laws. As a result of the 'war on drugs' and new sentencing policies, the United States currently has over 7 million people under the supervision of the criminal justice system. Of this number, more than 2 million people are incarcerated in local, state, and federal prisons and jails throughout the nation (U.S. Department of Justice, 2009).

According to the Pew Centre on the States (2008), the vast majority of incarcerated adults ( 91 percent) are under local or state jurisdiction, while the federal prison population continues to grow at a far more rapid rate than state prison populations. Despite the fact that over 200,000 people are locked up in federal correctional facilities, practical information about the Federal Bureau of Prisons (BOP) remains elusive. What we do know is that the federal prison system is a nationwide system of prisons and detention facilities for the incarceration of prisoners who have been sentenced to imprisonment for federal crimes and the detention of individuals awaiting trial or sentencing in federal court.

Prisons run by the BOP are spread throughout the country and comprise a range of correctional institutions, detention centres, medical centres, prison camps, metropolitan correctional centres, and penitentiaries. Each is organized according to five security levels: minimum, low, medium, high, and administrative. Offenders are classified and assigned to an institution based on such factors as severity of the offence, length of incarceration, type of prior commitments and history of violence (U.S. Department of Justice, 2009). The BOP is considered by many - including academics, practitioners, and those familiar with life or work within the federal prison system - to operate a better system than most state prisons. Generally, the prisons appear cleaner, with more amenities like food and programs, and the prison staff are better educated, trained, and paid (Roberts, 1994). 
Because of the nature of federal criminal law, prisoners in most federal facilities are thought to be different from those in state institutions. The image of federal prisoners being a more sophisticated type of criminal, from a higher socioeconomic status, who have committed crimes of extortion, mail fraud, bank robbery, and arson stems from the celebrity status of some BOP "clients" such as Alphonse Capone, G. Gordon Liddy, and Bernard Madoff. However, since the beginning of the "war on drugs" and "get tough on crime" approaches in the 1980s, the proportion of non-violent drug offenders has increased and now makes up approximately 60 percent of the incarcerated population. Fewer offenders (less than 15 percent of the federal prison population) have committed crimes of violence than are found in most state institutions. And, about 30 percent of federal prisoners are citizens of other countries (U.S. Department of Justice, 2009). Federal prisoners with celebrity status in free society are the minority within the contemporary federal prison system.

While the federal prison system may appear to operate a better prison system and house different clientele when compared to state prison systems, imprisonment in any American correctional setting involves exposure to deprivations that require prisoners to adapt to the setting within which they will reside for the duration of their sentence. Most Americans never even see, let alone become ensnared in, the nation's vast correctional system. But the unprecedented prison boom is incurring unprecedented costs - economic, social and ethical - that are being paid, one way or another, by everyone in this country. Prisons are an enormously costly failure for controlling and reducing crime, expensive beyond belief, debilitating, demeaning, counterproductive (Austin and Irwin, 2001; Ross and Richards, 2003), dangerous to prison staff and the non-violent majority who are imprisoned, and efficient breeders of even more serious future offenses against society. They only work to remove from the streets the relatively small percentage of persistently and irrationally violent, dangerous, and repeat offenders who happen to be apprehended by the agents of social control.

If you want to know how the criminal justice and penal machinery functions, then ask someone who has been in the system. Federal prisoners have a story to tell about their journey through the federal system of courts and prisons. This article provides the story of a former law enforcement officer, recent recipient of a graduate degree, and relatively new resident of the federal prison system who wanted to share his experience with the 
free world. He does not bemoan his current status as a federal prisoner nor does he play into the "I'm a victim of the system" argument. Rather, he notes the hypocrisy of the American criminal justice system. Specifically, the implementation of structured sentencing, the near-constant use of plea agreements to temper multiple count indictments by prosecutors, and the legal engineering of supposed justice that feeds an environment in which the mechanism of justice has become corrupted.

The federal prison experience presented here grows out of the collaborative effort of the authors to document the incarceration experience - from entry to release - and analyze that experience over the course of several years. The work presented reflects his initial entry into the federal prison system and adds to the growing body of literature and scholarly work on the impact of prison life on those who live it. We echo the call for prison reform efforts at all jurisdictional levels including the federal prison system. This is Andrew's story.

\section{THE FALL}

In the ancient federal system of Japan, warlords maintained a central form of government through the use of Samurai - devoted warriors to the state. These warriors unquestionably obeyed the edicts laid down for them by their masters and enforced the law with earnest zeal. They held themselves to a different standard, or warriors' code, which enabled them to operate outside the established standard to effectively enforce the law.

Occasionally through the political manipulations of their warlord masters, these Samurai warriors lost their honour and positions. Now masterless, they became wandering rouges and mercenaries. A pariah to the natural order, they often nevertheless maintained the central values of honour that made up the bulk of their previous existence. These fallen Samurai were called Ronin, and this is the story of a modern one.

I was a law enforcement officer, a cop, and by most standards a good and righteous one. I was a military professional, a highly decorated veteran of the Cold War, Desert Storm, and its aftermath. I was a scholar, pursuing my studies in the juggling act of academia and career. I was, in effect, everyone's all American; the kid next door; the local boy "done good". For fourteen years, I stood as the first line of defence for American freedoms and values. I swore oaths to the Constitution to uphold and defend it against enemies, both 
foreign and domestic. I had pride and honour, and the battle lines between right and wrong were clearly defined for me. I followed a warrior's code.

And now, I am a federal prisoner. With Thoreauian civil disobedience, I violated a law of my master that I thought unjust and, in turn, took full responsibility for my actions. Now I am a pariah, humbled by a system I truly believed in, a fallen knight of the realm. Ronin.

The purpose of this paper is not to elicit sympathy, but to demonstrate an example, for scholars and laymen alike, of how a man's view of justice and integrity are shaped by his experiences. Throughout my tribulation, I have tried to maintain my sense of honour and dignity, but have found it to be a daily struggle as I fight a mercilessly bureaucratic system. And while I have kept my values intact, I come to learn my previous master, the American Justice System, is a flawed and failing entity.

These are not sour grapes, borne out of bitterness of my situation, nor will I use this as a forum to attack our system of justice out of spite or vindictiveness. This is merely a warning, issued by a man who has seen both sides of the conflict. The implication is clear. The modern American system of justice is a failing entity. We, as a society, are creating a monster: an entire disenfranchised society within our own, full of second class citizens. As a country that prides itself on being the most free, we have more persons incarcerated per capita than any other country in the world. Even as our crime rate drops, our incarceration rate is rising. We are heading for a climax, as the costs for maintaining such a system outweigh our means of paying it.

The pragmatic goal of the justice system is to provide its citizenry with order, prosecute lawbreakers, rehabilitate them and return them to society. This classical societal 'maintenance' system infers that, regardless of the causation of criminal behaviour, once an offender receives his sanction and serves his sentence they can successfully be reintegrated back into society as a citizen. But this is not the case. The recidivism rate of criminals is very high, ranging from fifty to eighty percent by different accounts (Visher 2003). Why is this? Could it be that criminals are incorrigible, incapable of rehabilitation? Or could the answer lie in a more damning hypothesis - that once condemned by society and labeled as a criminal, an offender considers himself a noncitizen, unable to maintain the social bonding expected of a law abiding member of that society, even when they want to. Could it be that the conflict of rehabilitation and reintegration has given way to economic efficiency in 
our system of justice and machination of bureaucracy - this despite great leaps by society to make the pursuit of justice more equitable and fair?

I, for one, was convinced that our system of justice was clearly the best in the world. Innocent until proven guilty, the protections of the constitution, and the concept of equality under the law were at the forefront of my consciousness whenever the issue was raised. I have been in countries throughout the world where I worried about the legitimacy of my host's justice system, but never in my home country. My view of penology was conservative: an emphasis on education and rehabilitation, but at the expense of comfort. Prison was not supposed to be a nice place. It was negative sanctioning in the first degree and anyone there deserved to be there. After all, we have our constitutional safeguards, right? I believed that there were neither innocent persons in prison, nor unnecessarily severe punishment. The system would not allow it. Experience has taught me otherwise.

\section{MY PARTICULAR CASE}

As I am using my own case as an example of what is wrong with our system of justice, perhaps it will help the reader to understand the particulars of my situation. After the Cold War had ended, and Desert Storm completed, there was a diaspora of former military personnel out of the services and into the community. Like in so many previous instances of military draw downs, most of the former service men and women freely integrated back into society without difficulty. I was no exception. Based on my military background, I became involved in law enforcement. I started a law enforcement supply, became a federally licensed gun dealer and began a long process of law enforcement training. I soon became a deputy sheriff and had a relatively successful initial career. I was a good cop, yet somewhat over-zealous. I had been fed a steady diet of misinformation concerning criminals and criminality, and accepted it at face value.

My mind-set concerning the justice system was strengthened by my initial experiences. While certainly no angel growing up, I was the archetypal middle-class, rural, Caucasian cop. "Criminals" were easily identifiable to me as they were typecast the same in training and my initial experiences: stereotypes with characteristics, physical or otherwise (es tu Lombroso?). I I Ilearned to be suspicious of the lower economic classes, and minorities in particular, as they were the most likely to commit crime. I fell into a pattern 
of stereotyping criminals and criminality. Violent and property crime were my bane, and I gave a zealous performance in pursuit of drug offenders.

In the meantime, my fledgling gun business suffered the ups and downs associated with a small, first-time business. Balancing its success with my law enforcement career, military reserve service, and full-time college pursuit became a complex chore. In late 1993, my business on the brink of failure, I took a partner, a former customer with whom I had dealt for some time. Unfortunately, I did not check his background and this would be part of my undoing.

Surprisingly the anti-crime hysteria of 1994 proved to be a boom to my little business. I became very successful almost overnight. I was a federally licensed firearm manufacturer and dealer, a position that proved to be very important in the mad scramble by law enforcement and citizens alike that ensued in wake of the proposed anti-firearms provisions of the 1994 crime bill. I was no fool. From my law enforcement experience, I knew that firearms were hardly the bane to public order and safety that they claimed to be. In fact, I believed the mood of Congress to be an assault on the rights of free, law-abiding men. As a constitutional literalist, I felt that our second amendment rights to keep and bear arms were just as important as the First or Fourth Amendments - absolute cornerstones to our way of life.

It was because of this stance that, at the prodding of my business partner, I began to stockpile arms and manufacture fully automatic weapons. I could have easily paid an insignificant $\$ 500$ excise tax, coupled with my federal license, to produce and register these firearms without fear or repercussion. Unfortunately I did not, fearing registration leads to confiscation. In that instant I became a criminal, although I had no criminal intent. If anything, the firearms constituted a viable tool in my law enforcement duties. I would not be "out-gunned" by a criminal element to which the firearms provisions of the crime bill meant nothing.

In hindsight, what I did was foolish, while well-meaning. Although I had no intent of using any of those firearms in the course of committing a criminal act, it was the mere possession of them that constituted my criminality at a time when the hysteria of firearms being a bane to society was greatest. The inevitable conclusion, of course, would be that I would be punished for my crime.

It came without warning. By late 1997, I had shed myself of my business partner whom I felt was operating too far outside the law, and directed my 
full attention to my law enforcement career. I had begun to do great things in the community, clearing the drugs out of the local high school and involving myself in the lives of students. My previous infractions of firearm laws were long forgotten, my works either dismantled and destroyed, or locked away in a box in my home.

Unfortunately, my former business partner had felt the potential market for illicit firearms too great to ignore and continued to acquire and produce all manners of firearms for the black market. He quickly caught the attention of federal law enforcement agencies and, after a long investigation, was arrested and charged with a variety of firearm offences. At this point he was given a simple ultimatum: he would help his case greatly if he would implicate others, regardless of their level of involvement. Of course, I was the one implicated. What further compounded this was, unbeknownst to me, that my former business partner was already a convicted felon who had misrepresented himself, using me to gain access to firearms to begin with.

The agents came while I was in the middle of a narcotics investigation and caught me, and my department, greatly by surprise. They asked for my cooperation in their investigation and not sensing the trap, I fully agreed. These were, after all, fellow officers who needed information for the malfeasance of my former partner turned rogue. I cooperated but much to my horror the investigation turned towards me. I had implicated myself and the same offer of "helping" my case was given to me: implicate other officers and military personnel and I would get a light sentence. I refused. I could not help them; there was no one to implicate. My belief was that if they were truly interested in public safety then they would leave me alone to pursue the 'real' criminals in my community. But in their eyes my assumed non-compliance made me the 'real' criminal. It was a very awkward time.

Obviously, I became an instant pariah: my fellow officers, fearing that suspicion alone would wreck their career (and correctly so), turned away from me. I became an outcast in my own community. As I could not bear to see my good work condemned, I transferred my responsibilities to an up and coming young officer and tendered my resignation. I left the career I loved.

I was quickly picked back up by the Department of Defense (DOD) as a full-time National Guardsman. I was back in uniform, but the cloud of my legal trouble hung heavy in the air. Within a year, the answer would come. I would be indicted with firearm charges. Any hope for a law enforcement or military career was to be dashed. 


\section{ENTERING THE MACHINE}

Up to this point, I have no complaints as to the issues of justice. Clearly I violated the law, admitted to my wrongdoing, and faced the repercussions for my level of culpability. But after the indictment and my arrest, I suddenly found myself entering a judicial machine. My previous exposure to the felony workgroup as an officer gave me some basis of what to expect, but I was in no way prepared for what happened next.

My arrest was the understatement of subtlety. I received a call from the investigating officer who requested I meet him at the federal courthouse for processing. As I was coming from my DOD job, I was in uniform. Whisked into the Marshall's office, I was served with a G-charge indictment, fingerprinted, photographed, literally snuck into a courtroom before a magistrate, given bond and pre-release conditions, sent over to pre-trial services for the name of my pre-trial probation officer, and sent on my merry way. This all took place in the space of an hour. I was back to work before lunch. I've had misdemeanour arrests and processes take longer and I practically spun with dizziness from the event. I wonder to this day if the speed of my processing was because the court did not want negative press (since I was in uniform) or if it had more to do with shame, since looking at me they could see their own career mortality.

I returned to work, gathered my officer-supervisors and told them what had transpired, fully expecting to be released from duty (read "fired"). On the contrary, they were exceptionally supportive. I ended up staying in positions of responsibility, either in a full- or part-time capacity, for two years after this date. A month after my final judgement and commitment, I received an honourable discharge. I have nothing but the utmost respect for the defence establishment for their caring and protective nature during my crisis. They took care of their own.

But now $I$ was officially in trouble. I was referred to a criminal attorney (not so much an oxymoron as you might expect) who took my case for a paltry $\$ 4000$. While I should have been suspicious of the low amount requested for a fee, I never the less put my full faith and trust into this man. This was my second mistake.

The United States Attorney's Office provided my lawyer and me with the evidence to be presented against me. Aside from the physical evidence that I provided the agents when they first questioned me, the bulk of the 
"case" against me consisted of uncorroborated statements from other individuals, including my former partner, who were attempting to mitigate their prosecution. I have since learned that the majority of this "evidence" could not have been used against me in trial. Further, I have learned that most of the physical evidence, that is, the evidence I provided thus incriminating myself, was inadmissible as well. Unfortunately for me, my attorney was more interested in his role in the plea process to take note of this, as he was fully integrated in the felony workgroup - the defence, the prosecution, and the judge working in concert to elicit a guilty plea and thus speed prosecution. I was never given the opportunity to even prepare a defence as my attorney began to immediately negotiate a plea bargain (my third mistake).

While I desired a misdemeanour plea for my failure to pay the $\$ 500$ excise tax, the prosecution, especially the investigator, wanted a felony. Ostensibly, this was in retaliation for not revealing additional names or leads for them to continue an investigation. Privately, the investigator told me it was about politics, and his boss wanted additional gun convictions during the Reno Justice Department. While dissatisfied with the plea, I agreed to it anyway because after awhile the stress of the process and pressure from the attorneys (who want the simplest, least time-consuming method available) began to wear me down. Besides, the most culpable individual involved so far, my former business partner (who had actually sold upwards of twenty machine guns to undercover agents alone), had received an eighteen (18) month sentence. Another individual involved received probation. My attorney advised me that my level of involvement assured me of little or no incarceration time. I signed the plea bargain, but did not completely agree with the terms, as in waiving my right to appeal. Only later did I learn that the plea agreement is just that, a non-negotiable contractual arrangement (my fourth mistake).

After signing the plea agreement (by now it was no bargain), I waited a few weeks for it to be formalized during a Rule 11 plea colloquy before a magistrate. This is just another formality, but it had tremendous importance later. Because it was in an open court, and because the magistrate asked if I understood the ramifications of every point of the agreement (I didn't, but was advised by my attorney to agree to it anyway), I effectively eliminated most, if not all, of my constitutional protections. I had set myself up. By this time, I felt a noose slipping around my neck. During the Rule 11 hearing, I wanted to rise up and tell the magistrate, "NO! I don't agree to this". Apparently my angst was noticeable by the judge, who asked very slowly 
and deliberately if I understood the plea. I understood it all too well. I had been lured deeper into the machine and my paid advocate, my lawyer, was pushing me deeper still.

By this point I had learned to be distrustful of my attorney, and his compatriot, the Assistant U.S. Attorney. There was no longer an adversarial system at work here. Clearly, both my attorney and the Assistant U.S. Attorney had the same goals - for my submission to the felony workgroup. Now, I was a criminal. I could no longer plead the how's and why's of my behaviour. After the Rule 11 colloquially, I was totally subject to the machine, and it had another surprise for me: the preparation of the single most important document in federal judicial process - the Pre-Sentence Investigation Report, know as the PSI.

\section{THE PSI}

The PSI is prepared by a civil servant working for the Federal Department of Probation and Parole. In federal jurisprudence no one - not the investigator, prosecutor or even judge - has greater discretion and / or judicial power than this single probation officer. Ostensibly empowered to prepare a short, concise report on a guilty individual's culpability, the officer is allowed great latitude in what they put into the report, including undocumented hearsay evidence, past criminal history (including exonerations), work history, military experience and education. A synopsis of the crime is the bulk of the report. From there, the probation officer researches the federal manual for structured sentencing, the judicial bible of the federal sentencing process since 1986, and calculates the number of points assigned to one's crime. From these points, cross-referenced with one's previous criminal history, a range of months of incarceration is derived. A simple enough system in its overview, as individuals whose culpability is greater and have a more involved criminal history get more time. Unfortunately, especially in my case, those numbers can be stacked based on hearsay evidence and innuendo.

It took approximately a full year for my PSI to be completed. By this time, I had successfully completed my Bachelor's degree, applied for my Master's and began my graduate studies. I still worked on a part-time basis with the DOD after my graduate studies began, flying on humanitarian relief flights and other important missions. It was as if I was not involved in a criminal prosecution at all. My position as a graduate assistant afforded 
me opportunities to continue to train and advise law enforcement agencies, including state prison officials. It was an odd and paradoxical time. I felt like a fraud, ready to be outed at any time as some agent provocateur - "who let this criminal in the tent?" At the same time I was happy and proficient at my job, living the "good side" of my double life. It was not without tension, mostly on my end as I struggled with the duplicity, but I was accepted as a 'normal guy' by the cops. Apparently, no one got the memo about my label yet, or if they did they did not care. I was a Ronin in disguise.

Yet, despite my good deeds performed before and after my indictment, my PSI was crafted to make me look like a dangerous and unruly criminal. In addition to my base crime to which I pled, I was given copious amounts of sentencing enhancements, "bonus time", for comments and other hearsay evidence provided to the investigators by my former business partner and other implicated individuals. As my point total rose, I began to realize exactly what the Justice Department was doing. If I would not implicate others, then I was going to get as much time as could be loaded on top of me in order to pressure me to spill. My attorney did a lax job of complaining about my additional sentencing enhancements and we were only given 14 days to formally voice our objections. In the end, objections were raised, but they were so ill-constructed as to be practically useless. A first year law student could have done a more thorough job. My attorney was done with this "loser" case.

The final tally of points was shocking and disturbing. Rather than receiving the sentence of probation, or even the 18 months that my former partner received for his multiple violations, I was now looking at 46-56 months. I was stunned. How could I, who clearly had less culpability than anyone involved in the cases that led to mine, receive more time? Was structured sentencing not supposed to prevent this from happening? My attorney was non-perplexed. "Your background and public service will reduce your sentence", I was assured.

In February 2000 I went to my sentencing. I was nervous, of course, but had been assured that I would receive what is known as a "downward departure" in my sentence for my admission of responsibility and community work. Much to everyone's surprise, including my lawyer and the assistant U.S. Attorney, I did not. Rather, I received a 46-month sentence with 24 months of probation to follow. The judge, not familiar with my plea agreement, assured me that I could appeal his decision. I could not, as it was prohibited by sub-clauses of the agreement. 
I was crushed, stunned and in denial. How could this happen? How could someone who was clearly not a criminal, with no criminal mindset or intent, to whom rehabilitation was unnecessary, who had effectively provided the investigators with all pertinent information on himself- be given a sentence double in length of the individual more culpable? The answer: I had not cooperated enough. Admitting responsibility was not enough. The machine needed more fuel.

It was not over. I was given a year reporting extension by the sentencing judge in order to finish my graduate degree and teach a course in social deviance at my university. But by now, the full realization of what had transpired had begun to affect the participants. A few weeks after the sentencing, the judge contacted the Assistant U.S. Attorney, stating that he was unhappy that he was forced to give me such a stiff sentence and asked if something could be done to reduce it. The fact that he even was still thinking about it after several weeks is amazing. The Assistant U.S. Attorney conferred with my own attorney, again. For the year prior to my incarceration, the felony workgroup argued amongst themselves over who was at fault, and what, if anything could be done. The Assistant U.S. Attorney contacted my mother, reassuring her that everything was being done to remedy my case. The investigating agent was brought back into the mix with the hopes that I could give him additional information he could use on someone - anyone. There was a lot of hope but, in the end, all these efforts proved inadequate. My failure, my inability, to provide information to the government was what condemned me. I had not played the game right.

I wrapped up my fledgling career and began a rapid process of preparing for my four year hiatus into the federal prison system. I tied up loose financial ends, transferred all my remaining assets to my estranged wife and drove myself to prison with the aid of a former student. As I sat in a restaurant before reporting to the prison, I wondered if it was the right and moral thing to do. I felt wronged, humiliated and angry. I thought about skipping it all and heading to the various countries overseas that I was familiar with from my military time. In the end, I rationalized that I was a good citizen, even up to the end, and as a good citizen it was my obligation to accept my punishment. I surrendered to the Federal Bureau of Prisons Correctional Institute at Elkton, Ohio on April 2, 2001. I have never been in handcuffs and never been in a prison "cell", per se, but now I am quite definitely a prisoner, sharing living quarters with murderers, crack dealers 
and bank robbers. I am one of the disenfranchised. The one difference: I'm still a cop at heart - the cop that wants to help people in trouble and stop the bad guys. Now, I was a bad guy by definition. Pardon me while I look up irony and see my mug shot.

\section{CONCLUSIONS}

Please allow me to reintroduce an earlier point. The purpose of this work is not to induce sympathy, or cry for help to correct an injustice - the time for that has long sense passed. Nor is this borne out of bitterness and resentment. I consciously violated United States law; law crafted by our elected representatives for whatever intent they deemed necessary at the time. I was properly investigated, properly indicted, properly arrested, and even properly judged under the legal system's controls in place. And while there is some doubt as to the effectiveness of my counsel, I was afforded all my constitutional protections, as they were, at all stages of the process. Regardless of my personal feelings towards the law, which led to my civil disobedience, and subsequent refusal to pay the excise tax that led me to my current position, what I did was illegal and was punishable by the law of the United States. While I am not proud to be a convicted felon, I cannot be ashamed either. My conscience is clear. My problem lies in the instrument of justice itself. Somehow, we as a society have begun to remove a level of accountability from the justice system, which seems bizarre because that is exactly the opposite of what the reforms of the 1990s were said to achieve. Structured sentencing, plea agreements, and the multiple count indictment are creating an environment in which the mechanism of justice is being engineered with efficiency and expediency in mind. The result is a corruption of individual justice and personal accountability.

Finding criminals, prosecuting them, and entering them into a system is simple, regardless of what some law enforcement officials might have you believe. I state this from my own experience as a police officer. There are simply too many laws, too much redundancy, and far too many resources on the side of the justice system to prevent a criminal to "slip through the cracks". Once identified, a criminal is easy to catch, as their criminal behaviour is easy to track. Indeed, some case building operations are complex endeavours, and make for interesting and challenging exercises for law enforcement. But the simple reality is that, once identified and under 
scrutiny, case building is an elementary exercise: criminals and those who commit criminal acts (notice the separation), are generally either careless or cooperative when faced with exposure. Thus told, the old cop adage of "If asked, we could have every 'criminal' locked up within hours", is patently true. Great, then what?

Now the machine takes over and what an efficient little machine it is. The overwhelming mass of pending cases forces the criminal justice system to discard the concept of individual justice, culpability and accountability into a system of expediency. The felony work group - once again the defence attorney, prosecutor, and judge working in concert to keep the system moving regularly - often discount the merits of individual cases. No longer is the defence an advocate for innocence. Rather, the defence attorney is concerned with maintaining their client's freedom. The machine has little or no tolerance for a defendant fighting their case.

The proliferation and constant use of the plea agreement process has led us down this road. Defendants are expected to plead now and this affects the justice system all the way down to the front lines. As a young officer I was trained to charge a criminal with as many counts as possible to ensure the prosecutor had ample "negotiating space" for the plea process. The downfall, of course, is that potentially some defendants have no option to resist, as they simply do not have the energy or resources to defend themselves adequately. If law enforcement reform was intended to level the playing field, and remove the economic factors out of consideration, then we have failed.

Plea agreements themselves are subject to abuse both to the criminal and the victims (if any). Very often defendants plead out to behaviours not committed. Once again, I must hark about the individual accountability and culpability issue. This is in direct conflict with the law enforcement and prosecutorial desire of conviction "at all costs". Further, except in very narrow circumstances, the plea agreement generally limits or eliminates a convicted defendant's right to appeal, even if there are significant issues raised later.

Another issue of interest is the federal structured sentencing guidelines themselves. Aside from certain programs and sentencing options for drug abusers, there are no "safety valve" provisions for first-time offenders. Indeed, a first-timer is as culpable and responsible as a hardened career offender is, yet how is justice being best served? To this end, I could certainly argue with Dr. Stephen Mallory, Chairman of the Department of Criminal 
Justice at the University of Southern Mississippi, who stated unequivocally that there is no such thing as a first-time offender. I was. And if there is any doubt that the destruction of my law enforcement and military career, family, marriage, and finances was not enough punishment, then the four years I am spending in prison for essentially a tax crime certainly is more than enough. Safety valves would benefit the individual, as well as society economically and emotionally.

The major emphasis on sentencing reduction in federal prosecution is through cooperation as a government witness. These processes, called Federal rule of criminal procedure 35 (Rule 35) or Federal sentencing guideline chapter 5k.1 "Downward Departures", were designed to assist investigators and prosecutors, assign culpability to potential suspects, solidify cases, and implicate others in an investigation. Defendants look at the possibility of long prison sentences are encouraged, even pressured, to provide information (accurate or not) on other potential or actual suspects or defendants. The pragmatic goal, of course, is that the information provided will assign culpability upward, seeking out "higher level" offenders. This falls under an assumption that criminals are organized into some sort of hierarchy.

While this might be true for some drug or financial crimes, this does not apply across the board. In fact, as noted in my case, other, more culpable individuals provided the government with information (often untrue) implicating me and received substantial downward departures upon my plea acceptance. Lies, especially really good ones that give what the machine wants, outweigh context. In this respect, providing information in order to see a downward departure and mitigate one's own sentence becomes a game of musical chairs, albeit a serious one. Those individuals who are lower level players in the game and who do not have sufficient information to attract the interest of the prosecution are quickly left without a seat.

In addition, it is my belief that far too much emphasis is being placed on the merits of the PSI report. A single, unaccountable civil servant has greater judicial power than a federal judge with years of professional training and experience does. In the advent of structured sentencing, this effect was hailed as eliminating the human factor or emotion from corrupting the pursuit of justice, thus making the system equitable and fair. Yet, the framers failed to consider that the probation officer preparing the PSI is as human, and subject to biases and prejudices, as any judge, if not more so because of their law enforcement obligations. 
The PSI is a repository for information, both factual and alleged, that allows for an increase of a sentence without the judicial fairness of evaluation by trial. Hearsay, non-criminal but socially marginal information, and even criminal acquittals and exonerations may find their way into the PSI, thus slanting and downplaying an individual's positive attributes and emphasizing criminality or pseudo-criminality. If judges do not have enough discretion, then perhaps the preparer of the PSI report has too much. This is not to say that the defendant has no rebuttal to claims and sentencing enhancements in the PSI. In fact, a defendant has no more than 14 days to read, evaluate and make objection to any issues in the PSI. This is without the benefit of witnesses or supplementary evidence. 14 days, compared to months and years of preparation time allowed the Department of Justice. It seems vaguely unfair in its application.

Finally, all the issues I have raised would be null and void (to varying degrees) if federal judges would have sentencing discretion. Presently, judges have little to no discretion in applying a sentence less or more than what is provided for in the PSI report. Departing from the guidelines, whether upward or downward, can only be done in the narrowest of circumstances, and then it is often for a Rule 35 cooperation issue. Federal judges have been complaining for years about how their lack of discretion is harming the concept of criminal accountability, lost under the guise of fairness and equity. I understand the controversy - judges may give wildly disparate sentences for the same criminal behaviour, and may be tainted by racial, cultural, ethic or sexual prejudices. However, their human factor is the last possible "safety valve" left available to prevent injustice, and their years of experience and intellect has been effectively neutered by the machination of the justice system. By allowing judges to exercise more discretion, sentences like mine could be handled with the best interests of the public in mind, rather than forcing the judge to commit me for the guideline sentence. But the machine that is the current system does not like context, nor does it want to understand circumstances. The machine wants to be fed and it has an enormous appetite called bed space openings in our correctional facilities. I guess one could say I got too close to its funnel and got eaten.

In conclusion, I have learned a hard lesson. I know now that mistakes occur and that constitutional safeguards I always assumed were there sometimes are not enough. The justice system, my former master, has, indeed, shown its true face to me and has humbled me greatly. It has, intentionally or 
not, turned one of its knights into a Ronin: a dishonoured rogue. Yet, I am not finished. I will learn from my mistakes, identify the weaknesses and shortcomings of my former master, and make it accountable for its actions. I will not let conventional wisdom cloud the real and pressing issues facing our criminal justice system. Hopefully, my voice will be heard and joined by others before the system fails completely and the machine has consumed everyone.

\section{REFLECTIONS}

The gauge of success for any undertaking is the achievement of its prime objectives at acceptable cost over a reasonable span of time. The measure of a prison system's success would be the ultimate reduction of crime and the restoration of much of the prison population to law-abiding citizenry. By that standard, United States prisons have failed dismally. United States prisons today are dangerously overcrowded because of the myopia of too many judges, prosecutors, legislators, community leaders, editors, and wellmeaning, but frightened citizens who wrongly see prisons as the panacea for escalating crime. The clamour for more and stronger prisons, along with stiffer sentences makes no sense. We cannot build our way out of the crime problem.

And no matter what the length of the term, doing time in prison is a long, hard ride. Surviving imprisonment requires patience and humility. The imprisoned battle with time, the months and years that pass as one ages behind the wall. The differential effects of incarceration are well known. Sutherland et al. (1992, p. 524) noted that "Some prisoners apparently become 'reformed' or 'rehabilitated', while others become 'confirmed' or 'hardened' criminals". Similarly, we know that hundreds of thousands of prisoners who, although they were convicted of a crime, are not violent felons and pose little threat to the community. Many times, these individuals are sentenced to prison, for too long a time period (Austin and Irwin, 2001).

As prison populations remain large, so too will the number of individuals released back to the community. This is a compelling reason - and there are many other reasons - for doing all we can for civilizing corrections, reducing the number of men and women in prison, and lowering the rate of recidivism. The real problem is a societal one. As long as we have an indifferent and uneducated public with respect to crime issues, the deplorable state of American criminal justice policies and practices will continue. 


\section{REFERENCES}

Austin, James and John Irwin (2001) It's About Time, Belmont (CA): Wadsworth.

Pew Centre on the States (2008) "Pew report finds more than one in 100 adults are behind bars", Washington (D.C.). Retrieved from $<\mathrm{http}$ ://www.pewcenteronthestates.org/ news_room_detail.aspx?id=35912>.

Roberts, John W. (1994). Escaping Prison Myths: Selected Topics in the History of Federal Corrections, Washington (D.C.): American University Press.

Ross, Jeffrey I. and Stephen C. Richards (2003) Convict Criminology, Belmont (CA): Wadsworth.

Sutherland, Edward H., Donald R. Cressey and David F. Luckenbill (1992) Principles of Criminology, Dix Hills (NY): General Hall.

U.S. Department of Justice (2009) Quick Facts About the Bureau of Prisons, Washington (D.C.). Retrieved from $<$ http://www.bop.gov/about/facts.jsp $>$.

Visher, C. A. (2003) Transitions from Prison to Community: Understanding Individual Pathways, Washington (D.C.): The Urban Institute - Justice Policy Center.

\section{ABOUT THE AUTHORS}

Andrew Ferguson, MA, is a Lecturer of Criminology and Social Deviance for the Department of Sociology at Appalachian State University. He is also an Instructor for Homeland Security and Disaster Management for Appalachian's Department of Government and Justice Studies, as well as a consultant on issues of counter-terrorism to various militaries and public safety agencies throughout the world. He also teaches World Civilizations at a local community college. In 2009, he was sent to Kurdistan, Iraq through a U.S. State Department initiative to help rebuild the Kurd's collegiate Sociology programs. He currently resides in western North Carolina with his family and friends, and attempts to make up for the 4 years of his life lost during his incarceration by redefining the label of "ex-convict", mostly by ignoring it.

Barbara H. Zaitzow is Professor of Criminal Justice at Appalachian State University. Professor Zaitzow conducts a variety of research projects in men's and women's prisons, and has been involved in state and national advocacy work for prisoners and organizations seeking alternatives to incarceration. She has served on various editorial boards of nationally-recognized journals and has published a co-edited book, articles, and book chapters on a variety of prison-related topics including HIV/AIDS and other treatment needs of 
incarcerated women, as well as the impact of prison culture on the "doing time" experiences of the imprisoned. These works have appeared in the International Journal of Offender Therapy and Comparative Criminology, Journal of the Association of Nurses in AIDS Care, Journal of Crime and Justice, Criminal Justice Policy Review, Journal of Gang Research, Justice Policy Journal, The Prison Journal, Women's Studies Quarterly, and Names. 